\title{
Sustainable intensification: the pathway to low carbon farming?
}

\author{
Robert Martin Rees ${ }^{1}$ Andrew P. Barnes ${ }^{1} \cdot$ Dominic Moran $^{1}$
}

Received: 7 October 2016/Accepted: 7 October 2016/Published online: 5 November 2016

(C) Springer-Verlag Berlin Heidelberg 2016

\section{Introduction}

The food security agenda is now becoming clearly aligned with a need to tackle human-induced climate change. The ambitious agreements to mitigate the global emissions of greenhouse gases agreed by the United Nations Framework Convention on Climate Change (COP 21) summit at the end of 2015 in Paris have major implications for agriculture and land use. Agriculture is responsible for the production of $12 \%$ of global greenhouse gas emissions (IPCC 2013) and needs to be radically reformed to address the challenge of mitigation. At the same time, there is a need to increase global food supplies in order to meet the demands of a growing population (Godfray et al. 2010). Sustainable intensification has been advocated as an approach that can achieve these twin objectives (Wollenberg et al. 2015). A recent international conference in Edinburgh, UK explored the synergies and conflicts between increasing food productions and reducing the impact of such productions systems on the environment. The meeting also considered the issues from a global perspective and analysed regional challenges and solutions. This Special Issue of Regional Environmental Change includes a selection of three papers selected from the Edinburgh meeting.

As the twenty-first century progresses, our global systems of food production will come under increasing pressure. Central estimates of population growth predict a global population of 9 billion by 2050 (Beddington 2010), and much of that increase will occur in regions of the world already struggling to provide food for existing populations.

\footnotetext{
Robert Martin Rees

Bob.Rees@sruc.ac.uk

Scotland's Rural College, Edinburgh, UK
}

Even today, there are over 900 million people who go hungry, and probably a further billion that are malnourished. At the same time, we now recognize that we are in a phase of rapid human-induced climate change. Changes in temperature and rainfall distribution are predicted to accelerate during the twenty-first century and threaten to alter agricultural production across large areas of the world, as drought and extreme weather events disrupt traditional agricultural practices (IPCC 2014).

Agriculture and climate change have become increasingly interlinked in the debate of the sustainability of food production. The true contribution of agriculture to greenhouse gas emissions is often underestimated (Bell et al. 2014); although $12 \%$ of direct global emissions are reported to result from agricultural production, when the wider effects of land use change and food production and distribution are included, the total is over $30 \%$. So rather uniquely, agriculture needs to both mitigate and adapt to climate change. This is likely to involve significant changes to the ways in which we manage farming systems in the coming decades. During the twentieth century, large increases in productivity were achieved through significant increases in inputs to agricultural systems. Low energy and commodity prices coupled with land use change allowed global cereal production to double between 1961 and 2011 . However, the increasing environmental burden of such intensification has become increasingly apparent, and it is unlikely that this old model could be repeated. We need therefore to uncouple growth in agricultural production from the adverse environmental impacts with which this has historically been associated. The extrapolation of current trends would indicate a tripling of the input of reactive $\mathrm{N}$ to the global environment, much of which would be used to support food production (Fowler et al. 2015). Such increases would have highly damaging impact on the 
environment in terms of air, soil and water pollution, and alternative pathways of development are urgently sought. We need to explore opportunities to increase the efficiency of resource use within farming, where efficiencies are driven by inputs decoupled from environmental harm and greater productivity is increasingly reliant on a renewable resource base. The magnitude of the change in systems and mechanisms needed for such a transitional change could be huge and in some cases possibly insurmountable. Increasing resource use efficiency, will require farming systems to improve utilization of energy, use nutrients and pesticides more efficiently, make more extensive use of smart and spatially explicit precision management approaches to farming, exploit new biological and genetic opportunities for improvement and reduce waste. These technological changes must be coupled with shifts in behaviour and consumption at the production, supply chain and consumption levels. Indeed, improving our knowledge of agricultural systems and developing technologies to changing and expanding farming practice is critical. Of equal importance to technological fixes, are the step changes needed in the translation of research results into practice. Ensuring consistent throughput of innovation within the systems is reliant on appropriate and targeted information, and support for on-farm decision-making. In addition, institutional change and support, specific to each region, is needed in terms of supply chain function, organization and information flow.

This Special Issue provides some important research messages that will help inform the future direction of the Sustainable Intensification debate. Three papers are included. The first by Chagunda et al. (2016) describes how smallholder dairy farms have adopted sustainable intensification in Sub-Saharan Africa. Smallholder farming makes an important contribution to food production in the region and approaches by which increased productivity from the sector is being achieved with reduced environmental impacts are described. There are three main routes by which this is achieved; through ecological intensification where new approaches such as agroforestry or the production of new forages are promoted; genetic intensification, involving the genetic improvement of livestock used in smallholder systems; and socio-economic intensification, which develops as a result of increased training and knowledge of production systems allowing farmers to achieve higher levels of production per unit of input.

The second paper provides an analysis by Barnes (2016), who argues that sustainable intensification must achieve increased food production with lower environmental impacts. However, there is a gap between the technical potential of what is possible through interventions in farming systems and what is actually achieved. This is a consequence of barriers including social and economic issues which are often overlooked but crucial to determining successful policy outcomes which aim to deliver more sustainable food production and consumption.

In order to achieve significant improvements in efficiency of food production systems, it will be essential to reduce overall wastage within the supply chain. In the third paper of this Special Issue, Porter and Reay (2016) report that over $30 \%$ of all food production is wasted leading to detrimental environmental impacts including greenhouse gas emissions. In developed countries, much of these losses are associated with downstream portions of the supply chain (processing, distribution and consumption), whilst in less developed countries, losses are mostly associated with upstream activities including agricultural production post production handling and storage. Various approaches to the reduction of wasted food production are described in developed and developing countries.

The papers presented here cover a wide diversity of topics related to the sustainable intensification debate and in doing so illustrate the scale of the challenge associated with the redesign of our agricultural systems means that we need to engage widely and inclusively with society to ensure that pressures are exerted on the future supply and demand for food from our farming systems.

\section{References}

Barnes AP (2016) Can't get there from here: attainable distance, sustainable intensification and full-scale technical potential. Reg Environ Change, pp 1-10. doi:10.1007/s10113-015-0916-9

Beddington J (2010) Global food and farming futures. Philos Trans R Soc B Biol Sci 365:2767. doi:10.1098/rstb.2010.0181

Bell MJ, Cloy JM, Rees RM (2014) The true extent of agriculture's contribution to national greenhouse gas emissions. Environ Sci Policy 39:1-12. doi:10.1016/j.envsci.2014.02.001

Chagunda MGG, Mwangwela A, Mumba C, Dos Anjos F, Kawonga BS, Hopkins R, Chiwona-Kartun L (2016) Assessing and managing intensification in smallholder dairy systems for food and nutrition security in Sub-Saharan Africa. Reg Environ Change, pp 1-11. doi:10.1007/s10113-015-0829-7

Fowler D, Steadman CE, Stevenson D, Coyle M, Rees RM, Skiba UM, Sutton MA, Cape JN, Dore AJ, Vieno M, Simpson D, Zaehle S, Stocker BD, Rinaldi M, Facchini MC, Flechard CR, Nemitz E, Twigg M, Erisman JW, Butterbach-Bahl K, Galloway JN (2015) Effects of global change during the 21st century on the nitrogen cycle. Atmos Chem Phys Discuss 15:13849-13893. doi:10.5194/acp-15-13849-2015

Godfray HCJ, Beddington JR, Crute IR, Haddad L, Lawrence D, Muir JF, Pretty J, Robinson S, Thomas SM, Toulmin C (2010) Food security: the challenge of feeding 9 billion people. Science 327:812-818. doi: $10.1126 /$ science. 1185383

IPCC (2013) Climate Change 2013: The Physical Science Basis. Contribution of Working Group I to the Fifth Assessment Report of the Intergovernmental Panel on Climate Change [Stocker, T.F., D. Qin, G.-K. Plattner, M. Tignor, S.K. Allen, J. Boschung, A. Nauels, Y. Xia, V. Bex and P.M. Midgley (eds.)]. Cambridge University Press, Cambridge, United Kingdom and New York, NY, USA, pp 1535 
IPCC (2014) Summary for policymakers. In: Climate Change 2014: Impacts, Adaptation, and Vulnerability. Part A: Global and Sectoral Aspects. Contribution of Working Group II to the Fifth Assessment Report of the Intergovernmental Panel on Climate Change [Field, C.B., V.R. Barros, D.J. Dokken, K.J. Mach, M.D. Mastrandrea, T.E. Bilir, M. Chatterjee, K.L. Ebi, Y.O. Estrada, R.C. Genova, B. Girma, E.S. Kissel, A.N. Levy, S. MacCracken, P.R. Mastrandrea, and L.L. White (eds.)]. Cambridge University Press, Cambridge, United Kingdom and New York, NY, USA, pp 1-32
Porter SD, Reay DS (2016) Addressing food supply chain and consumption inefficiencies: potential for climate change mitigation. Reg Environ Change, pp 1-12. doi:10.1007/s10113-0150783-4

Wollenberg L, Richards M, Havlik P, Smith P, Carter S, Herold M (2015) Will sustainable intensification get us to 2 degrees Celsius? L2:68-69. Montpellier, France. Climate smart agriculture, 2015. Global science conference 